\title{
HUBUNGAN CUSTOMER SATISFACTION DAN BRAND EXPERIENCE DENGAN BRAND IMAGE TERHADAP CUSTOMER LOYALTY: STUDI KASUS PENGELOLAAN MAL
}

\author{
Helen dan Emrus ${ }^{1}$ \\ Universitas Pelita Harapan \\ Jl. M.H. Thamrin, Boulevard, Tangerang Banten \\ Helen@ \\ Emrus.fisip@uph.edu
}

\begin{abstract}
The development of department stores or known as malls is growing up significantly from years to years and making the tight competition in retail world in Indonesia. The entire malls attempt to win the customers loyalty by using the appropriate marketing strategy for the targeted consumers. This effort will be balanced with the good perception towards the brand image that the mall has. Mall $X$ is the research object. This research is conducted to measure the influence of customer satisfaction, brand experience, and brand image toward the customer loyalty of Mall X, which is the brand image is treated as the intervening variable. The data collection starts with the questionnaires that spreaded among 240 respondents and being analyzed with Structural Equation Model (SEM) technique. The result shows from the five hypothesizes which had been tested, three of those hypothesizes showing the positive relationship.
\end{abstract}

Key Words: Customer Satisfaction, Brand Experience, Brand Image, Customer Loyalty

\begin{abstract}
Abstrak: Pengembangan pusat perbelanjaan atau dikenal dengan mal yang tumbuh secara signifikan dari tahun ke tahun, dan membuat persaingan yang ketat di dunia ritel di Indonesia. Seluruh mal mencoba untuk memenangkan loyalitas pelanggan dengan menggunakan strategi pemasaran yang tepat untuk konsumen yang ditargetkan. Upaya ini akan seimbang dengan persepsi yang baik terhadap pencitraan yang dimiliki mal tersebut. Objek dalam penelitian ini adalah Mal X. Penelitian ini dilakukan untuk mengukur pengaruh dari kepuasan pelanggan, pengalaman terhadap merek, dan citra merek terhadap loyalitas pelanggan mal X, dimana citra merek menjadi variabel antara. Pengumpulan data didapatkan dari kuesioner yang disebarkan kepada 240 responden dan dianalisis dengan teknik Structural Equation Model (SEM). Hasil penelitian ini menunjukkan dari lima hipotesisi yang telah diuji, tiga diantaranya menunujukkan hubungan positif.
\end{abstract}

Kata Kunci: Kepuasan Pelanggan, Pengalaman terhadap Merek, Citra Merek, dan Loyalitas Pelanggan

\section{Pendahuluan}

Tren kebutuhan berbelanja masyarakat perkotaan terus meningkat seiring dengan perkembangan zaman. Pusat perbelanjaan atau mal menghadirkan berbagai macam kenikmatan. Mulai dari tersedianya berbagai kebutuhan yang diinginkan (one stop shopping) hingga tempat yang tepat untuk bersantai bersama keluarga maupun kolega (Tempo 2004).

\footnotetext{
${ }^{1}$ Penulis utama adalah Helen mahasiswa UPH yang dalam proses penelitian dan penulisan dibimbing oleh Emrus Dosen UPH.
} 
Meningkatnya kebutuhan one stop shopping juga mempengaruhi tingkat pertumbuhan pusat perbelanjaan, yang lebih dikenal dengan istilah mal. Pertumbuhan pusat perbelanjaan atau mal di Jakarta yang tidak cuma modern tetapi juga gemerlap, karena telah menjadi gaya hidup yang tidak dapat lepas dari masyarakat Jakarta (Tempo Interaktif 2006). Berbelanja telah menjadi ciri masyarakat yang hidup di zaman kontemporer dewasa ini (Soedjatmiko 2008, 2).

Bukan saja berfungsi sebagai tempat membeli kebutuhan sehari-hari, seperti fashion, F\&B (food and beverages), household utilities, kebutuhan usaha atau bisnis, dan lainnya, mal juga menjadi tempat yang marak untuk menghabiskan waktu senggang para pengunjung. Masyarakat Jakarta yang kerap menjadikan mal sebagai obat depresi dan stress. Fakta ini membuat developer terus mengembangkan ide mereka untuk membangun pusat perbelanjaan yang memiliki banyak fungsi (Vivanews 2011). Salah satu perkembangan ide tersebut terwujud dalam peralihan mal yang bukan hanya menjadi tempat hiburan keluarga yang juga buka untuk hiburan malam (Media Indonesia 2011).

Konsumen atau pengunjung mal yang ada di Indonesia, terutama di kota besar seperti daerah Jakarta, terdiri dari berbagai kelas konsumen yang berbeda pula. Setiap mal menargetkan konsumen yang sesuai dengan positioning/ penempatan identitas mereka di mata konsumen untuk mendapatkan keuntungan. Bidikan mal yang mencakup mulai dari konsumen tertentu yang menjadi target, penempatan citra mal di pasaran dan benak konsumen, dan prospek target konsumen yang ingin dicapai juga menjadi faktor-faktor yang penting bagi mal dalam mengembangkan kualitas usaha dan memuaskan konsumen mereka. Hal ini didukung dengan pernyataan Barsky (1992) bahwa kepuasan pelanggan merupakan salah satu kunci keberhasilan suatu usaha.

Jumlah mal yang terdapat di Jakarta sendiri adalah 130 mal (Harian Seputar Indonesia 2011) di 2011, setelah sebelumnya di tahun 2008 hanya terdapat 60 buah mal. Dengan persaingan antar mal yang semakin kompetitif sekarang ini penting bagi pihak perusahaan yang mengelola mal untuk dapat membangun brand image atau citra merek yang baik di mata konsumen. Keller $(2008,51)$ menjelaskan bahwa brand image melambangkan karakteristik dari brand/ merek sehingga dapat dijadikan sebagai keunggulan brand tersebut. Brand image dibangun dengan memunculkan persepsi yang baik dalam benak konsumen. Persepsi yang baik dari konsumen muncul dari kepuasaan konsumen atau customer satisfaction dalam menilai kembali pengalaman menggunakan brand tersebut. Hal ini tidak lepas kaitannya dengan pengalaman langsung konsumen atau brand experience yang menjadi penentu dalam munculnya kepuasan atau ketidakpuasan terhadap mal tersebut. 
Persaingan kompetitif antara mal yang satu dengan yang lain di kota besar dalam menggaet konsumen mereka membuat mal yang ada perlu berefleksi akan brand image mal masing-masing dan cara untuk meningkatkan rasa kepercayaan konsumen. Dengan brand image yang baik konsumen akan semakin tertarik untuk mengunjungi mal tersebut dan menimbulkan perilaku belanja yang setia atau dikenal dengan customer loyalty.

Sikap konsumen yang telah mencicipi suasana belanja mal dibentuk dengan persepsi konsumen atas kepuasan atau ketidakpuasaan konsumen terhadap kondisi dan kelengkapan mal. Konsumen yang mempunyai persepsi mal yang baik karena brand experience mereka yang merasa puas dan senang. Hal ini akan bepengaruh baik pada brand image mal dan mengarah ke arah customer loyalty. Tidak ada satupun bisnis atau organisasi yang dapat sukses tanpa membangun kepuasan dan keloyalitasan pelanggan (Timm 2005).

Mal X merupakan salah satu mal di Jakarta Pusat yang berdiri sejak awal tahun 1982 dan terus bertahan sampai sekarang dengan lingkungan yang semakin kompetitif. Mal X merupakan salah satu mal di Jakarta Pusat yang mempunyai traffic visitor mal yang cukup tinggi karena lokasinya yang strategis di pusat kota (Data Mal X 2011). Maraknya aneka ragam mal yang ada di Jakarta, khususnya di Jakarta Pusat, membuat Mal X harus dapat bersaing dengan mal lainnya yang juga mempunyai target konsumen yang sama dengan Mal X.

Brand experience konsumen menjadi prioritas utama Mal X dalam melakukan peningkatan kualitas mal sehingga dapat menjadikan pengalaman belanja konsumen pada Mal X sebagai suatu kegiatan yang memuaskan, menyenangkan, dan mendorong pengalaman berikutnya untuk kedepannya. Persepsi konsumen akan brand image Mal X yang negatif akan berakibat pada kesulitan dalam mendapatkan dan mempertahankan customer loyalty. Mal X sebagai sebuah mal yang professional wajib melakukan perbaikan dalam peningkatan kualitas mal sehingga dapat menjadi sebuah mal dengan brand image yang baik dan mempertahankan customer loyalty mereka. Selain dari pada itu, Mal X dapat memaksimalkan pengalaman belanja atau brand experience konsumen menjadi hal yang bersifat baik, berkualitas dan menyenangkan.

Customer satisfaction dan brand experience yang maksimal bagi konsumen dalam saat belanja mereka di Mal X merupakan faktor yang dapat mengarah ke penciptaan brand image yang baik dimata konsumen Mal X dan berujung ke customer loyalty. Brand image dalam pengaruhnya disini mendapat perlakuan sebagai variabel intervening (Sandjaja dan Heriyanto 2006, 85), yang artinya faktor yang secara teoritik ikut mempengaruhi hubungan antara variabel dependent dan variabel independent. 


\section{Rumusan Masalah}

Rumusan masalah yang ingin diteliti adalah sebagai berikut:

1) Apakah terdapat hubungan antara customer satisfaction konsumen Mal X dengan brand image Mal X?

2) Apakah terdapat hubungan antara brand experience konsumen Mal X dengan brand image Mal X?

3) Apakah terdapat hubungan antara customer satisfaction konsumen Mal X dengan customer loyalty Mal X?

4) Apakah terdapat hubungan antara brand experience konsumen Mal X dengan customer loyalty Mal X?

5) Apakah terdapat hubungan antara brand image konsumen Mal X dengan customer loyalty Mal X?

\section{Manfaaat Penelitian}

Penelitian diharapkan dapat memberikan kegunaan akademis. Penelitian memberikan kontribusi bagi teori mengenai pengaruh customer satisfaction, brand experience, dan brand image terhadap customer loyalty. Karena itu, penelitian ini dapat meningkatkan pemahaman konseptual mengenai ketiga variabel di atas yang mempengaruhi customer loyalty. Penelitian ini juga untuk mendukung kebenaran teori mengenai customer loyalty yang telah ada sebelumnya.

\section{Tinjauan Pustaka}

Komunikasi merupakan kegiatan yang tidak dapat lepas dari kehidupan sehari-hari manusia. Pengaplikasian komunikasi pada kegiatan perusahaan dapat terwujud melalui berbagai bentuk kegiatan, yang salah satunya adalah kegiatan marketing komunikasi. Kegiatan marketing komunikasi merupakan kegiatan komunikasi pemasaran yang dilakukan oleh perusahaan untuk mempromosikan dan mengiklankan perusahaan atau brand tertentu. Kegiatan marketing memerlukan promosi yang berhubungan dengan fungsi komunikasi pemasaran.

Membangun sebuah merek merupakan keseluruhan objektivitas dari kegiatan marketing komunikasi (Duncan \& Ouwersloot 2008, 38). Pengertian dari brand/ merek menurut Keller $(2008,2)$ adalah: 
A brand is a "name, term, sign, symbol, design, or a combination of them, intended identify the goods and services of one seller or group of sellers, to differentiate them from those of competition.

Kunci untuk menciptakan sebuah brand adalah mampu memilih sebuah nama, logo, symbol, desain kemasan, atau karakteristik lain untuk dapat mengidentifikasikan sebuah produk dan membedakannya dari yang lain. Definisi brand/ merek menurut Rangkuti (2002, 35):

Merek adalah nama, simbol, istilah, atau desain khusus yang dirancang untuk mengidentifikasikan barang atau jasa yang ditawarkan oleh penjual.

Dengan pengertian merek yang telah dijabarkan, dapat disimpulkan bahwa pada dasarnya sebuah brand terdiri dari persepsi dan bukan hanya sekedar logo atau simbol (Duncan dan Ouwersloot, 2008, 28). Brand hadir untuk ditujukan secara spesifik agar berpengaruh dalam pikiran konsumen.

Brand yang diteliti dalam penelitian ini adalah Mal X. Penelitian ini membahas dua bagian dari aspek yang berkaitan dengan brand, yaitu brand experience dan brand image.

\section{Pengertian Brand Experience}

Untuk dapat mengetahui kualitas brand/ merek hal ini erat kaitannya dengan pengalaman konsumen atau pelanggan. Pengalaman konsumen berperan penting dalam menentukan persepsi konsumen mengenai brand tersebut.

Menurut Landa (2006, 9), brand experience dapat diartikan sebagai berikut: "Brand experience is an individual audience member's experience as he or she interacts with a brand--every time he or she interacts with that brand."

Setiap interaksi dengan suatu brand akan membentuk pengalaman dengan brand dan bepengaruh terhadap keseluruhan persepsi konsumen. Persepsi tersebut dapat berupa persepsi yang positif, negatif, atau netral terhadap brand. Brand dan apa yang dilambangkannya bagi konsumen yang telah merasakan dan mengalami pengalaman dengan brand tersebut dapat mempengaruhi apa yang konsumen bersedia lakukan untuk sebuah produk atau jasa (Duncan \& Ouwersloot 2008, 39).

Dalam penelitian ini, brand experience konsumen dari Mal X yang ingin diteliti diukur berdasarkan empat skala yang dikembangkan oleh Brakus, Schmitt, \& Zarantonello (2009, 52- 
68). Peneliti ingin melihat brand experience konsumen Mal X dilihat dari segi sensory, affective, behavioural, dan intellectual.

\section{Pengertian Brand Image}

Image atau citra merupakan hal yang penting bagi konsumen dalam menentukan pilihan mereka atas sebuah produk atau jasa. Duncan $(2005,82)$ mendefinisikan brand image sebagai: "Kesan yang diciptakan oleh pesan dan pengalaman merek, yang diasimilasikan ke dalam suatu persepsi tentang merek." Karakteristik merek, nama, simbol, kemasan dan reputasi merupakan kombinasi jasa yang dapat menciptakan kesan keseluruhan atau brand image dalam benak konsumen.

Menurut Davis (2000, 53-72), brand image memilki dua komponen, yaitu brand Associations (asosiasi merek) dan brand personality (kepribadian merek). Brand associations merupakan informasi lainnya mengenai suatu merek yang berhubungan dengan kesimpulan informasi mengenai merek dalam memori dan mengandung arti dari merek tersebut bagi konsumen. Brand personality merupakan serangkaian karakteristik manusia yang oleh konsumen diasosiasikan dengan merek tersebut, seperti: kepribadian, penampilan, nilai, kesukaan, gender, ukuran, bentuk, etnis, inteligensi, kelas sosial ekonomi dan pendidikan. Hal ini membuat brand seakan-akan hidup dan mempermudah konsumen mendeskripsikannya, serta faktor penentu apakah konsumen ingin diasosiasikan dengan merek tersebut atau tidak.

\section{Pengertian Consumer Satisfaction}

Salah satu tujuan dari pemasaran adalah menghasilkan kepuasan pelanggan terhadap merek atau customer satisfaction. Kepuasan dapat terbentuk karena adanya kualitas yang diterima penggunaan merek atau produk tertentu. Menurut Kotler (1994, 40), satisfaction dapat diartikan: “the level of a person's felt state comparing a product's perceived performance (or outcome) on reaction to the person expectation." Pengertian yang diungkapkan Giese \& Cote (2000) berhubungan dengan sebuah respon keseluruhan yang bersifat emosional dalam bermacammacam intensitas dengan jangka waktu yang spesifik dan terbatas yang ditentukan terhadap fokus pencapaian dan penggunaan produk.

Dimitriades $(2006,785)$ membedakan kepuasan konsumen menjadi dua tingkatan, yaitu cumulative satisfaction dan transaction-spesific satisfaction. Cumulative atau overall satisfaction (kepuasan secara menyeluruh) merupakan kepuasan konsumen atas evaluasi yang berdasarkan 
pada total pembelian dan pengalaman pada saat mengkonsumsi produk sepanjang waktu. Kepuasan secara menyeluruh termasuk relatif stabil sepanjang waktu (Baran, Galka, \& Strunk 2008, 319). Sedangkan, transaction-spesific satisfaction (kepuasan transaksi spesifik) merupakan kepuasan konsumen yang berdasarkan pada hal-hal yang spesifik yang dijumpai oleh konsumen tersebut pada perusahaan. Kepuasan yang diperoleh mungkin akan berbeda dari setiap pengalaman.

\section{Pengertian Customer Loyalty}

Kotler $(2009,163)$ mengutip definisi dari customer loyalty menurut Oliver adalah sebagai "A deeply held commitment to rebuy or repatronize a preferred product or service in the future despite situational influences and marketing efforts having the potential to cause switching behaviour."

Definisi tersebut menjelaskan bahwa loyalitas pelanggan atau konsumen merupakan suatu komitmen mendalam dalam melakukan pembelian ulang terhadap suatu produk atau jasa pada masa yang akan datang dengan dipengaruhi oleh pengaruh situasi dan usaha pemasaran yang menyebabkan perilaku perpindahan dari merek lainnya.

Dalam studi terkini menurut Ganesh, Arnold, \& Reynolds (2000), pengukuran loyalitas merek didasarkan atas intensi berlangganan atau membeli kembali. Ganesh, Arnold, \& Reynolds (2000) merumuskan pengukuran loyalitas konsumen dengan menggunakan indikator-indikator, yaitu: repeat patronage (berlangganan kembali), self-stated retention (ingin menjadi pelanggan yang setia), price insensitiviy (ketidakpekaan terhadap harga), resistance to counterpersuasion (tahan terhadap bujukan), dan the likelihood of spreading positive word of mouth (kemungkinan untuk memberikan rekomendasi positif). Pengukuran loyalitas dalam penelitian ini menggunakan referensi dari Ganesh, Arnold, \& Reynolds (2000).

\section{Pengertian Social Exchange Theory (SET)}

Social exchange theory (SET) atau yang dikenal dengan teori pertukaran sosial dikembangkan oleh John Tribaut dan Harold Kelly (West \& Turner 2007, 205). Menurut West \& Turner (2007, 205), SET didefinisikan sebagai "Social Exchange Theory (SET) is based on the notion that people think about their relationships in economic term and that they tally up the costs and compare them to the rewards that are offered by being in each relationship." 
Konsep SET didasarkan bahwa orang-orang mempunyai pandangan ekonomis dalam hubungan mereka dengan orang lain dan mereka mengenal prinsip harga atau costs dan membandingkannya dengan keuntungan atau rewards yang mereka dapatkan dalam setiap hubungan tersebut. West \& Turner $(2007,205)$ mengutip pendapat Monge \& Contractor (2003) mengenai perspektif dalam SET bahwa orang menghitung keseluruhan kelayakan dalam sebuah hubungan dengan mengurangi costs dari rewards yang didapatkan, dengan perhitungan sebagai berikut: Worth $=$ rewards- costs.

Prinsip SET menjadi acuan pada setiap hubungan yang dimiliki konsumen dengan suatu brand yang menjadi minat konsumen. Pada penelitian ini Mal X merupakan brand (merek) yang diteliti hubungannya dengan konsumen. Mal X akan dapat menarik konsumen jika mereka menawarkan keuntungan yang dianggap konsumen lebih dibanding dengan mal lainnya yang dapat menawarkan keuntungan serupa. GMP tentunya mengharapkan hubungan pertukaran yang bersifat productive exchange dengan konsumen, yang akan dapat terjadi jika dapat menjaga kesinambungan kepuasan dan loyalitas konsumen mereka. Kaitan lengkap antara SET akan dibahas pada pembahasan hasil hipotesis yang diuji.

\section{Kaitan antara Customer Satisfcation dengan Brand Image}

Customer satisfaction merupakan hasil dari persepsi konsumen terhadap nilai yang didapat dalam sebuah transaksi atau hubungan dimana nilai tersebut setara dengan kualitas yang didapat dibandingkan dengan harga dan biaya akuisisi pelanggan (Blanchard \& Galloway, 1994; Heskett et al., 1990). Persepsi yang didapat tersebut merupakan bagian dari brand image perusahaan yang dimiliki oleh konsumen.

Peter \& Olsen $(2003,148)$ menjelaskan bahwa kepuasan pelanggan dapat mempengaruhi brand image perusahaan dan perusahaan dapat meningkatan kepuasan pelanggan melalui brand image yang baik pula.

\section{Kaitan antara Brand Experience dengan Brand Image}

Menurut Zarantenello \& Schmitt (2000), brand experience dapat secara positif mempengaruhi kepuasan konsumen dan persepsi konsumen mengenai brand tersebut. Hal ini sesuai dengan definisi brand experience yang dijelaskan oleh Alloza (2008) mengenai brand experience, yang merupakan persepsi konsumen dalam setiap kontak atau hubungan konsumen 
dengan brand tersebut. Persepsi tersebut kemudian akan disimpan sebagai brand image dalam memori konsumen terhadap perusahaan yang bersangkutan.

Kesuksesan dalam memberikan janji yang dikomunikasikan akan memberikan pengaruh positif dalam benak konsumen sehingga akan mendorong konsumen untuk mempunyai brand image yang baik terhadap brand tersebut secara otomatis.

\section{Kaitan antara Customer Satisfaction dengan Customer loyalty}

Kotler \& Keller (2006, 135-7) menyatakan bahwa tujuan akhir dari aktivitas bisnis sekarang ini adalah membuat high customer satisfaction agar tercipta high customer loyalty (loyalitas konsumen yang tinggi). Kotler \& Keller menyatakan penting dengan menciptakan customer satisfaction yang tinggi maka loyalitas konsumen yang tinggi akan turut tercipta pula. Perusahaan yang ingin bersaing harus dapat membuat pelanggan merasa sangat puas (high satisfaction), karena pelanggan yang merasa hanya cukup puas (just satisfied) masih mudah berganti ke produk/layanan lain apabila mendapat tawaran lain atau insentif yang lebih baik.

Peter \& Olson $(2005$, 45) mengatakan jika kepuasan dari konsumen itu telah terpenuhi maka konsumen akan melakukan pembelian ulang serta mendapatkan persepsi atau pemikiran yang positif yang akan dapat diceritakan kepada orang lain. Customer satisfaction mengarahkan konsumen terhadap tindakan pembelian ulang dan persepsi yang positf. Pembelian ulang disini merupakan kegiatan yang terjadi yang merupakan tahapan awal dari customer loyalty.

\section{Kaitan antara Brand Experience dengan Customer Loyalty}

Brand experience yang positif akan membuat konsumen merasakan suatu interaksi yang positif pula dengan brand yang menyebabkan konsumen akan melakukan kegiatan pembelian atau penggunaan ulang terhadap merek tersebut atau loyalitas. Sejalan dengan pernyataan Baek, Kim, \& Yu (2010) bahwa brand experience dianggap sebagai salah satu faktor yang penting yang menghubungkan hasil akhir yang diharapkan dalam mencapai loyalitas terhadap merek dan relationship marketing.

Menurut Landa (2006, 9) tujuan utama brand experience adalah untuk menambah kepercayaan dan loyalitas dari konsumen mereka. Landa menyimpulkan bahwa dengan adanya brand experience konsumen yang baik/ positif, maka loyalitas pelanggan dapat diciptakan, dan tujuan dari brand experience konsumen tersebut pun dapat terpenuhi. Jadi dapat disimpulkan 
dengan brand experience konsumen yang semakin positif/ meningkat, maka customer loyalty pun akan semakin positif/ meningkat.

\section{Kaitan antara Brand Image sebagai Variabel Intervening dengan Customer Loyalty}

Mengukur brand image perusahaan membantu untuk mengidentifikasikan kekuatan dan kelemahan brand sebagaimana persepsi konsumen terhadap produk atau layanan (Faircloth et al., 2001). Hal ini didukung dengan pernyataan Hsieh, Pan, \& Setiono $(2004,252)$ bahwa brand image yang sukses memungkinkan konsumen untuk mengetahui kebutuhan yang dipenuhi oleh brand tersebut dan membedakannya dengan kompetitor yang ada, sehingga secara konsekuen akan meningkatan kemungkinan pembelian kembali konsumen terhadap brand tersebut. Dengan konsumen mengidentifikasi brand image terhadap brand, konsumen dapat mengetahui apakah brand tersebut tepat memuaskan kebutuhan mereka sehingga jika terdapat hasil yang positif maka konsumen akan beralih ke tingkat loyalitas.

\section{Hipotesis}

H1: terdapat hubungan positif customer satisfaction dengan brand image

H01: tidak terdapat hubungan positif customer satisfaction dengan brand image

$\mathrm{H} 2$ : terdapat hubungan positif brand experience dengan brand image

H02: tidak terdapat hubungan positif brand experience dengan brand image

H3: terdapat hubungan positif antara customer satisfaction dengan customer loyalty

H03: tidak terdapat hubungan positif antara customer satisfaction dengan customer loyalty

H4: terdapat hubungan positif antara brand experience dengan customer loyalty

H04: tidak terdapat hubungan positif antara brand experience dengan customer loyalty

H5: terdapat hubungan positif antara brand image sebagai variabel intervening dengan customer loyalty

H05: tidak terdapat hubungan positif antara brand image sebagai variabel intervening dengan customer loyalty 


\section{Model Penelitian}

Bedasarkan hipotesis yang didapat, kerangka pemikiran yang dibuat sesuai dengan model penelitian sebagai berikut:

\section{Gambar 1. Model Penelitian}

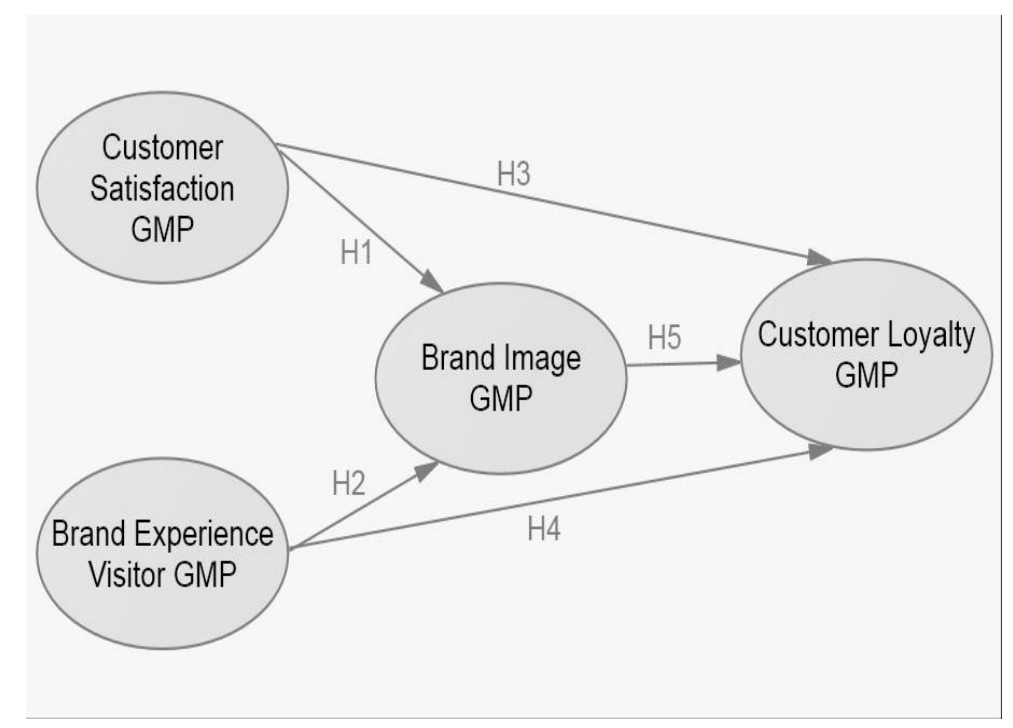

Sumber: Olahan Peneliti 2011

\section{Metode Penelitian}

\section{Objek dan Subjek Penelitian}

Menurut Zikmund (2003, 104), spesifikasi yang jelas mengenai unit analisis diperlukan untuk memberikan pedoman dalam menentukan dari mana data harus diperoleh. Unit analisis suatu penelitian terdiri dari dua hal yaitu objek penelitian dan subjek penelitian.

Objek penelitian ini adalah Mal X yang merupakan mal di Jakarta Pusat yang dikenal secara luas oleh masyarakat Jakarta, khususnya daerah Jakarta Pusat. Alasan pemilihan Mal X sebagai objek penelitian adalah pertama, peneliti ingin mengamati bagaimana pendapat konsumen mengenai Mal X sendiri. Kedua, peneliti mendapatkan akses yang mudah dari perusahaan dalam mendapatkan data dan keterangan dari perusahaan.

Subjek penilaian yaitu individu atau organisasi yang diteliti untuk memperoleh jawaban atas objek yang diteliti. Subjek dari penelitian ini adalah konsumen atau visitor Mal X sendiri yang mengunjungi Mal X dalam keseharian aktifitas mereka. Alasan pemilihan terhadap visitor Mal X karena memenuhi target responden yang ingin diteliti oleh peneliti dan memudahkan proses pengumpulan data yang tepat bagi penelitian. 


\section{Jenis Penelitian}

Jenis penelitian yang digunakan survey korelasional yang bersifat eksplanatif, menggambarkan hubungan antar variable. Penelitian ini berusaha menggambarkan hubungan antara customer satisfaction dan brand experience terhadap customer loyalty, dengan brand image sebagai variabel intervening.

\section{Definisi Operasional Variabel}

Definisi operasional memberikan arti terhadap sebuah konsep dengan menjelaskan aktifitas yang diperlukan untuk mengukurnya (Sekaran 2003, 176). Definisi operasional dari masingmasing variabel yang terdapat dalam penelitian ini dijelaskan pada Tabel 1. Pada Tabel 1 terdapat indikator-indikator dari masing-masing variabel yang mewakili pertanyaan-pertanyaan pada kuesioner.

\section{Tabel 1. Definisi Operasional Variabel}

\begin{tabular}{|c|c|c|c|}
\hline Variabel & Dimensi & Indikator & Skala \\
\hline \multirow[t]{2}{*}{$\begin{array}{l}\text { Customer } \\
\text { Satisfaction }\end{array}$} & $\begin{array}{l}\text { Cumulative } \\
\text { satisfaction }\end{array}$ & $\begin{array}{l}\text { 1. Efektifitas pelayanan di Mal X memuaskan. } \\
\text { 2. Kinerja para pegawai di Mal X baik. } \\
\text { 3. Mal X menyediakan tempat hiburan yang lengkap. }\end{array}$ & \multirow[t]{2}{*}{$\begin{array}{c}\text { Likert } \\
(1-5)\end{array}$} \\
\hline & $\begin{array}{l}\text { Transaction- } \\
\text { spesific } \\
\text { satisfaction }\end{array}$ & $\begin{array}{l}\text { 4. Mal X memberikan promosi bulanan yang tepat bagi para konsumen } \\
\text { dalam berbelanja. } \\
\text { 5. Mal X mengadakan bazzar murah meriah yang disukai konsumen di } \\
\text { atrium mal. } \\
\text { 6. Harga produk di Mal X terjangkau. }\end{array}$ & \\
\hline \multirow[t]{4}{*}{$\begin{array}{l}\text { Brand } \\
\text { Experience }\end{array}$} & Sensory & $\begin{array}{l}\text { 1. Saya menyukai pengaturan interior di Mal X. } \\
\text { 2. Pemasangan iklan di Mal X dapat dilihat secara jelas. }\end{array}$ & \multirow[t]{4}{*}{$\begin{array}{c}\text { Likert } \\
(1-5)\end{array}$} \\
\hline & Affective & $\begin{array}{l}\text { 3. Mal X membuat saya merasa nyaman dalam setiap kunjungan saya. } \\
\text { 4. Berbelanja di Mal X menyenangkan. }\end{array}$ & \\
\hline & Behavioral & $\begin{array}{l}\text { 5. Saya merasa diuntungkan dengan mengikuti acara yang diadakan Mal } \\
\mathrm{X} \text {. }\end{array}$ & \\
\hline & Intellectual & $\begin{array}{l}\text { 6. Pegawai Mal X ramah dalam memberikan informasi. } \\
\text { 7. Mal X menyediakan pengalaman belanja yang inovatif. } \\
\text { 8. Mal Mal X memberikan pandangan yang bagus bagi konsumen } \\
\text { mengenai mal yang lengkap. }\end{array}$ & \\
\hline \multirow[t]{2}{*}{$\begin{array}{l}\text { Brand } \\
\text { Image }\end{array}$} & $\begin{array}{c}\text { Brand } \\
\text { Associations }\end{array}$ & $\begin{array}{l}\text { 1. Mal X merupakan salah satu mal yang cukup tua yang ada di Jakarta. } \\
\text { 2. Toko hewan peliharaan Mal X terkenal di kalangan konsumen. } \\
\text { 3. Lokasi Mal X di Jakarta Pusat startegis. } \\
\text { 4. Keamanan Mal X merupakan prioritas mal. } \\
\text { 5. Letak Mal X yang berdekatan dengan China Town menyebabkan } \\
\text { banyaknya kalangan etnis Chinese menjadi konsumen Mal X. }\end{array}$ & \multirow[t]{2}{*}{$\begin{array}{c}\text { Likert } \\
(1-5)\end{array}$} \\
\hline & $\begin{array}{c}\text { Brand } \\
\text { Personality }\end{array}$ & 6. Mal X berkonsep modern yang mengikuti perkembangan tren. & \\
\hline \multirow[t]{2}{*}{$\begin{array}{l}\text { Customer } \\
\text { Loyalty }\end{array}$} & $\begin{array}{c}\text { Repeat } \\
\text { patronage }\end{array}$ & $\begin{array}{l}\text { 1. Saya akan berbelanja di Mal X lagi. } \\
\text { 2. Mal X merupakan mal yang menjadi pilihan utama saya dalam } \\
\text { berbelanja. }\end{array}$ & \multirow[t]{2}{*}{$\begin{array}{c}\text { Likert } \\
(1-5)\end{array}$} \\
\hline & $\begin{array}{l}\text { Self-stated } \\
\text { retention }\end{array}$ & $\begin{array}{l}\text { 3. Saya bangga menjadi pelanggan Mal X. } \\
\text { 4. Saya tertarik mengikuti program loyalty reward bagi konsumen setia } \\
\text { di Mal X. }\end{array}$ & \\
\hline
\end{tabular}

Sumber: Olahan Peneliti 2011 (Referensi: Dimitriades, 2006; Brakus, Schmitt, \& Zarantonello, 2009; Davis 2000; Ganesh, Arnold, \& Reynolds, 2000) 


\section{Teknik Pengumpulan Data}

Dalam metode pengumpulan data, sumber data yang akan digunakan adalah data primer. Data primer adalah data yang diperoleh dari sumber pertama baik dari individu seperti hasil wawancara, pengisian kuesioner, maupun dari hasil observasi langsung untuk analisis berikutnya untuk menemukan solusi atau masalah yang diteliti (Sekaran 2003, 219). Penelitian ini menggunakan instrumen guna mendapatkan data primer dari pengisian kuesioner oleh responden. Kuesioner adalah serangkaian pertanyaan yang dibuat secara sederhana, dan bertujuan untuk mengumpulkan data yang dibutuhkan dalam suatu penelitian (Sekaran 2003, 239).

Metode penyebaran kuesioner yang diterapkan dalam penelitian ini adalah dengan kuesioner dilakukan sendiri. Pengertian dari kuesioner yang dilakukan sendiri menurut Sekaran (2003, 257) adalah peneliti membagikan langsung kuesioner tersebut kepada responden. Keunggulan dari metode ini adalah pertama, tidak memakan biaya besar jika diberikan kepada responden secara berkelompok. Kedua, tingkat pengembalian kuesioner yang telah diisi oleh responden dapat mencapai hampir 100\%. Ketiga, nama dari responden tidak ditanyakan sehingga kerahasiaan dari indentitas responden terjaga. Keempat, jika ada pertanyaan yang tidak jelas maka dapat langsung ditanyakan kepada peneliti (Sekaran 2003, 239).

\section{Teknik Penyusunan Kuesioner}

Teknik pembuatan kuesioner dalam penelitian ini menggunakan tipe pertanyaan yang bersifat tertutup (closed question), dimana responden tinggal memilih salah satu dari alternatif jawaban yang telah disediakan oleh peneliti (Aaker dan Day 1990, 242).

Penggunaan pertanyaan tertutup membantu responden dalam membuat keputusan dengan cepat untuk memilih di antara beberapa pilihan yang tersedia. Selain itu, pertanyaan yang bersifat tertutup membutuhkan waktu yang lebih sedikit dibandingkan dengan menggunakan pertanyaan terbuka dan keuntungan yang paling mendasar adalah jawaban dapat dibandingkan langsung dari responden yang satu dengan yang lainnya (Aaker dan Day 1990, 242).

\section{Sampel}

Sampel diartikan sebagai bagian dari populasi yang dipilih untuk ikut serta dalam proses penelitian (Malhotra 2002, 346). Dengan mempelajari sampel maka peneliti dapat menarik kesimpulan yang dapat digeneralisasikan terhadap populasi penelitian. Menggunakan sampel 
daripada populasi dalam pengumpulan data karena dalam penelitian yang melibatkan beberapa ratus dan bahkan ribuan elemen, secara praktis mustahil untuk mengumpulkan data, menguji, atau menelaah setiap elemen. Selain itu juga meminimalkan biaya dan waktu dalam pengumpulan data (Sekaran 2003, 267).

Dalam penelitian ini desain sampel yang dipakai adalah teknik sampel nonprobabilitas (nonprobability sampling). Sampel nonprobabilitas adalah desain pemilihan sampel yang mana semua elemen populasi tidak memiliki peluang yang sama untuk dipilih menjadi anggota sampel (Umar 2003, 106; Sekaran 2003, 276). Metode pengambilan sampel yang digunakan peneliti adalah purposive sampling. Alasan digunakannya purposive sampling karena penelitian memerlukan anggota populasi yang memang telah ditujukan untuk memenuhi kriteria tertentu yang diperlukan. Judgment sampling merupakan tipe dari purposive sampling yang sesuai digunakan dalam penelitian ini karena memilih sampel yang sesuai berdasarkan kriteria yang telah ditetapkan untuk memberikan informasi.

Dalam penelitian ini kriteria untuk pemilihan sampel adalah responden yang merupakan konsumen Mal X yang mempunyai pengalaman belanja di Mal X. Konsumen Mal X yang dimaksud di sini adalah pengunjung dari Mal X yang telah mempunyai pengalaman belanja di Mal X, seperti transaksi belanja dan menggunakan fasilitas Mal X, sekurang-kurangnya empat kali. Kriteria kunjungan sekurang-kurangnya empat kali yang ditetapkan karena mengacu pada indikator dengan variabel brand image, karena memerlukan konsumen yang mempunyai pengalaman dan pengetahuan yang cukup mengenai Mal X agar dapat diukur persepsinya.

\section{Analisis Data pada Studi Pendahuluan}

Suatu kuesioner dikatakan baik apabila sudah melewati uji validitas. Menurut Zikmund (2003, 203), validitas atau keabsahan adalah kemampuan dari pengukuran instrumen untuk mengukur apakah instrumen tersebut yang diharapkan untuk diukur. Jika sesuatu sudah sangat andal mengukur sebuah konsep membuat stabilitas dan konsistensi yang tinggi, tetapi itu belum tentu merupakan konsep mengukur hal yang tepat. Validitas memastikan kemampuan dari sebuah skala untuk mengukur konsep yang diharapkan (Sekaran 2003, 205).

Menurut Sekaran (2003, 206-8), uji validitas dikelompokan menjadi dua yang terdiri dari content validity dan construct validity. Content validity digunakan untuk mengukur apakah variabel-variabel yang digunakan dalam penelitian valid atau tidak. Sedangkan construct validity menguji seberapa baik hasil yang diperoleh dari sebuah pengukuran sesuai pada teori yang mendesain tes. 
Korelasi dalam validitas konvergen dapat dilihat dengan menggunakan Exploratory Factor Analysis (EFA). EFA mempunyai tujuan utama untuk menjelaskan sejumlah variabel sebagai indikator dengan tingkat kontrol yang terbatas dari peneliti untuk menjelaskan faktornya.

Jenis pengujian validitas selain dengan EFA dapat dilakukan berdasarkan nilai corrected item-total correlation. Nilai corrected item-total correlation merupakan pengukuran untuk melihat validitas konstruk. Corrected item-total correlation (item-to-total correlation) adalah nilai yang digunakan untuk menunjukan apakah indikator yang ada telah mewakili dengan baik variabel bentukan yang dikembangkan (Ghozali 2004, 135). Hair et al. $(2006,137)$ mengatakan nilai minimum untuk corrected item-total correlation adalah 0,5. Sedangkan Trinton dan Hariwijaya $(2005,249)$ mengatakan bahwa nilai corrected item-total correlation di atas 0,3 menandakan bahwa variabel dapat diandalkan.

Nilai corrected item-total correlation yang sesuai pada penelitian jika dihitung berdasarkan degree of freedom $(d f)$ penelitian yang berjumlah 48 dan tingkat kepercayaan yang diberikan adalah 95\% (tingkat error yang diijinkan dalam penelitian adalah 5\%) menghasilkan $r_{\text {hitung }}$ sebesar 0,24. Degree of freedom (df) didapat dari jumlah sampel atau jumlah responden dikurangi $2(\mathrm{df}=\mathrm{N}-2)$, dimana dalam studi pendahuluan ini terdapat 50 responden. Dengan demikian, $d f=50-2=48$. Studi pendahuluan akan dikatakan valid jika mempunyai nilai $r_{\text {tabel }}$ di atas 0,24 .

Berdasarkan Tabel 2 dapat dibuktikan validitas konvergen pada pre-test telah tercapai

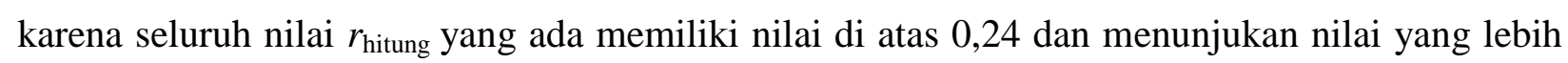
besar dari $r_{\text {tabel }}$ yaitu 0,24 .

\section{Uji Reliabilitas Studi Pendahuluan (pre-test)}

Menurut Hair et al. (2006, 137), uji keandalan adalah sebuah penilaian sederajat konsistensi antara berbagai pengukuran dari sebuah variabel. Sedangkan menurut Sekaran (2003, 203), uji keandalan memperlihatkan konsistensi dan stabilitas dari pengukuran instrumen.

Terdapat beberapa cara untuk mengukur keandalan suatu konsep dalam penelitian. Penelitian ini menggunakan jenis internal consistency reliability yang digunakan untuk mengakses sebuah skala rumus dimana beberapa pernyataan (items) dirumuskan untuk membentuk total nilai pada sebuah konstruk (Hair et al. 2003, 243). Tipe dari internal consistency reliability yang digunakan adalah dengan metode Cronbach's alpha. Sekaran (2003, 307) mendefinisikan Cronbach's alpha adalah koefesiensi keandalan yang menunjukan seberapa 
baik hal dalam sebuah kumpulan berhubungan positif antara satu dengan yang lain. Menurut Hair, et al. (2006, 137), Cronbach's alpha merupakan yang paling sering digunakan untuk mengukur nilai keandalan dari data yang dikumpulkan.

Tabel 2. Hasil Uji Validitas Studi Pendahuluan

\begin{tabular}{|c|c|}
\hline \multicolumn{2}{|c|}{ Corrected item-total correlation } \\
\hline CS1 & 0.449 \\
CS2 & 0.417 \\
CS3 & 0.304 \\
TS1 & 0.468 \\
TS2 & 0.457 \\
TS3 & 0.514 \\
SE1 & 0.327 \\
SE2 & 0.322 \\
AF1 & 0.449 \\
AF2 & 0.460 \\
BE1 & 0.271 \\
IN1 & 0.333 \\
IN2 & 0.520 \\
IN3 & 0.518 \\
AS1 & 0.391 \\
AS2 & 0.432 \\
AS3 & 0.376 \\
AS4 & 0.600 \\
AS5 & 0.544 \\
PE1 & 0.384 \\
RE1 & 0.417 \\
RE2 & 0.617 \\
SS1 & 0.630 \\
SS2 & 0.454 \\
\hline Sumber : Olahan Peneliti 2011
\end{tabular}

Tabel 3 Hasil Uji Reliabilitas Studi Pendahuluan

\begin{tabular}{|c|c|}
\hline Variabel & Croncbach's Alpha \\
\hline $\begin{array}{c}\text { CustomerSatisfaction } \\
- \text { - CS1 } \\
\text { - CS2 } \\
\text { - } \text { CS3 } \\
\text { - TS1 } \\
\text { - } \text { TS2 } \\
\text { - } \text { TS3 }\end{array}$ & 0,703 \\
\hline $\begin{array}{c}\text { Brand Experience } \\
-\mathrm{SE} 1 \\
-\mathrm{SE} 2 \\
-\mathrm{AF} 1 \\
-\mathrm{AF} 2 \\
-\mathrm{BE} 1 \\
-\mathrm{IN} 1 \\
-\mathrm{IN} 2 \\
-\mathrm{IN} 3\end{array}$ & 0,710 \\
\hline $\begin{array}{l}\text { Brand Image } \\
\text { - AS1 } \\
\text { - AS2 } \\
\text { - AS3 } \\
\text { - AS4 } \\
\text { - AS5 } \\
\text { - PE1 }\end{array}$ & 0,717 \\
\hline $\begin{array}{l}\text { Customer Loyalty } \\
-\quad \text { RE1 } \\
-\quad \text { RE2 } \\
-\quad \text { SS1 } \\
- \text { SS2 }\end{array}$ & 0,732 \\
\hline
\end{tabular}

Nilai terendah untuk Cronbach's alpha adalah 0,6 (Hair et al. 2006, 137). Nilai reliabilitas data yang andal untuk menganalisis data dengan menggunakan model persamaan struktural (SEM) adalah lebih besar dari 0,7 (Hair et al. 2000, 612).

Pengujian pre-test yang dilakukan untuk mendapatkan nilai uji reliabilitas terhadap 50 responden dapat dilihat pada tabel 4.5 .

Berdasarkan Tabel 3 dapat disimpulkan bahwa variabel-variabel yang ada dalam penelitian ini andal karena seluruh nilai Cronbach’s alpha memiliki nilai di atas 0,7.

\section{Teknik Analisis Data Penelitian Aktual}

Dalam penelitian ini teknik analisis data yang digunakan adalah Structural Equation Model (SEM). Penggunan SEM memungkinkan untuk dapat menjawab pertanyaan penelitian yang bersifat regresif maupun dimensional, untuk mengukur apa dimensi-dimensi dari sebuah konsep. Dalam menghadapi pertanyaan penelitian berupa identifikasi dimensi-dimensi pada 
sebuah konsep atau konstruk dan pada saat yang sama ingin mengukur pengaruh atau derajat hubungan antar faktor yang telah diidentifikasikan dimensinya, maka SEM merupakan alternatif jawaban yang layak dipertimbangkan (Ferdinand 2002, 7).

SEM merupakan program yang berguna untuk melakukan pengujian terhadap sebuah model yang rumit menggunakan analisis faktor dan persamaan simultan. Analisis faktor pada umumnya menggunakan likelihood ratio chi-square test yang berguna untuk mengukur tingkat kesesuaian model hipotesis dengan data yang didapat. Dalam perkembangannya analisis faktor mengalami peningkatan yang dapat menguji hipotesis berkaitan dengan factor loading nya disebut dengan analisis faktor konfirmatori (confirmatory factor analysis) (Ghozali 2008, 3-4).

Analisis data yang menggunakan CFA untuk memastikan indikator sebuah konstruk. Adapun faktor loading masing-masing indikator harus 0,5 atau lebih secara ideal harus 0,7 atau lebih (Hair et al. 2006, 777). Loading significant dari CFA dapat dilihat dari critical ratio (nilai kritis). CR yang lebih besar dari 1,96 sehingga nilai loading tersebut signifikan dengan kepercayaan $90 \%$ yang ditetapkan pada penelitian actual ini. CFA merupakan bagian dari measurement model pada SEM. Sedangkan, pengujian hipotesis pada penelitian menggunakan pengujian structural model pada SEM. Penelitian ini menggunakan software SPSS versi 18 dan AMOS versi 18.

\section{HASIL DAN PEMBAHASAN}

\section{Profil Responden}

Kuesioner yang disebar pada penelitian aktual dilakukan kepada 240 responden. Tabel 4 menjelaskan profil responden pada penelitian aktual.

Tabel 4. Profil Responden, $n=240$

\begin{tabular}{|c|l|r|r|}
\hline No & Data Responden & Jumlah & Presentase \\
\hline \multirow{3}{*}{1} & Jenis Kelamin & & \\
\cline { 2 - 4 } & Wanita & 134 & $55.8 \%$ \\
\cline { 2 - 4 } & Pria & 106 & $44.2 \%$ \\
\hline \multirow{4}{*}{2} & Usia & & \\
\cline { 2 - 4 } & $<18$ & 19 & $7.9 \%$ \\
\cline { 2 - 4 } & $18-25$ & 43 & $17.9 \%$ \\
\cline { 2 - 4 } & $26-33$ & 61 & $25.4 \%$ \\
\cline { 2 - 4 } & $34-41$ & 77 & $32.1 \%$ \\
\cline { 2 - 4 } & $42-29$ & 25 & $10.4 \%$ \\
\cline { 2 - 4 } & $>50$ & 15 & $6.3 \%$ \\
\hline
\end{tabular}

\begin{tabular}{|c|l|r|r|}
\hline No & Data Responden & Jumlah & Presentase \\
\hline 3 & Penghasilan & & \\
\cline { 2 - 4 } & $<1.500 .000$ & 64 & $26.7 \%$ \\
\cline { 2 - 4 } & $1.500 .000-2.000 .000$ & 79 & $32.9 \%$ \\
\cline { 2 - 4 } & $2.000 .001-2.500 .000$ & 59 & $24.6 \%$ \\
\cline { 2 - 4 } & $2.500 .001-3.000 .000$ & 18 & $7.5 \%$ \\
\cline { 2 - 4 } & $>3.000 .000$ & 20 & $8.3 \%$ \\
\hline 4 & Frekuensi kunjungan & & \\
\cline { 2 - 4 } & 4 kali & 147 & $61.3 \%$ \\
\cline { 2 - 4 } & 5 kali & 52 & $21.7 \%$ \\
\cline { 2 - 4 } & $\geq 6$ kali & 41 & $17.1 \%$ \\
\hline
\end{tabular}

Sumber: Olahan Peneliti 2011 


\section{Analisis Reliabilitas Penelitian Aktual}

Analisis reliabilitas penelitian aktual menggunakan rumus reliabilitas konstruk yang menunjukan data dapat diandalkan jika nilai reliabilitas masing-masing konstruk di atas 0,7 . Rumus yang digunakan untuk melihat nilai construct reliability adalah:

$$
\text { Construct Reliability }=\frac{\left(\sum \text { standardized loading }\right)^{2}}{\left(\sum \text { standardized loading }\right)^{2}+\sum \varepsilon j}
$$

Nilai construct reliability yang lebih besar dari 0,70 menunjukan bahwa instrumen penelitian dapat diandalkan (Ferdinand 2002, 192). Namun, bila nilai construct reliability di antara 0,6-0,7, maka hasil masih dapat diterima dengan predikat baik.

Tabel 5 Hasil Pengukuran Construct Reliability

\begin{tabular}{|c|c|c|c|c|c|c|c|}
\hline Konstruk & $\begin{array}{l}\text { Indika- } \\
\text { tor }\end{array}$ & $\begin{array}{l}\text { Standard } \\
\text { Loading }\end{array}$ & $\begin{array}{c}\text { (Estandard-ized } \\
\text { loading) }\end{array}$ & $\begin{array}{c}\text { (Estandardi-ized } \\
\text { loading) }^{2}\end{array}$ & $\begin{array}{c}\varepsilon \\
\text { (error) }\end{array}$ & $\sum \varepsilon$ & $\begin{array}{l}\text { Construct } \\
\text { Reliability }\end{array}$ \\
\hline \multirow{4}{*}{$\begin{array}{c}\text { Customer } \\
\text { Satisfaction }\end{array}$} & CS1 & 0,801 & \multirow[t]{4}{*}{3,043} & \multirow[t]{4}{*}{9,260} & 0,338 & \multirow[t]{4}{*}{1.644} & \multirow[t]{4}{*}{0,849} \\
\hline & $\mathrm{CS} 2$ & 0,883 & & & 0,779 & & \\
\hline & $\mathrm{CS} 3$ & 0,755 & & & 0,430 & & \\
\hline & TS1 & 0,604 & & & 0,635 & & \\
\hline \multirow{2}{*}{$\begin{array}{c}\text { Brand } \\
\text { Experience }\end{array}$} & AF2 & 0,535 & \multirow[t]{2}{*}{1,259} & \multirow[t]{2}{*}{1,585} & 0,714 & \multirow[t]{2}{*}{1,190} & \multirow[t]{2}{*}{$\mathbf{0 , 5 7 1}$} \\
\hline & SE1 & 0,724 & & & 0,476 & & \\
\hline \multirow[t]{5}{*}{ Brand Image } & AS1 & 0,635 & \multirow[t]{5}{*}{3,398} & \multirow[t]{5}{*}{11,546} & 0,597 & \multirow[t]{5}{*}{2,678} & \multirow[t]{5}{*}{$\mathbf{0 , 8 1 2}$} \\
\hline & AS2 & 0,681 & & & 0,536 & & \\
\hline & AS3 & 0,612 & & & 0,625 & & \\
\hline & AS4 & 0,750 & & & 0,438 & & \\
\hline & AS5 & 0,720 & & & 0,482 & & \\
\hline Customer & RE1 & 0,968 & \multirow[t]{2}{*}{1,699} & \multirow[t]{2}{*}{2,887} & 0,028 & \multirow[t]{2}{*}{0,520} & \multirow{2}{*}{$\mathbf{0 , 8 4 7}$} \\
\hline Loyalty & RE2 & 0,713 & & & 0,492 & & \\
\hline
\end{tabular}

Sumber: Olahan Peneliti 2011

Dari Tabel 5 dapat dilihat bahwa semua variabel, kecuali variabel brand experience, memiliki nilai construct reliability yang baik karena telah mencapai nilai 0,7 . Nilai variabel brand experience dapat diabaikan karena variabel lainnya mempunyai nilai construct reliability yang cukup tinggi.

\section{Analisis Validitas Penelitian Aktual}

Analisis validitas data penelitian aktual menggunakan confirmatory factor analysis (CFA). Data akan mencapai validitas konstruk jika factor loading setiap indikator terhadap konstruknya di atas 0,5 dan 0,7 dan signifikan dengan nilai critical ratio di atas 1,96 dengan confidence interval sebesar 90\% yang digunakan pada penelitian ini. Tabel 6 menunjukan hasil CFA pada penelitian aktual. 
Tabel 6. Hasil Confirmatory Factor Analysis (CFA)

\begin{tabular}{|c|c|c|c|c|c|c|}
\hline & & Path Diagram & Estimate & $\begin{array}{c}\text { Standard } \\
\text { Regression } \\
\text { Weights } \\
\end{array}$ & CR & $\mathbf{P}$ \\
\hline CS1 & $<--$ & Customer_Satisfaction & 1.000 & 0.801 & & \\
\hline $\mathrm{CS} 2$ & $<--$ & Customer_Satisfaction & 1.061 & 0.883 & 14.447 & $* * *$ \\
\hline CS3 & $<--$ & Customer_Satisfaction & 0.883 & 0.755 & 11.821 & $* * *$ \\
\hline TS1 & $<--$ & Customer_Satisfaction & 0.734 & 0.604 & 9.168 & $* * *$ \\
\hline AS1 & $<--$ & Brand_Image & 1.000 & 0.635 & & \\
\hline AS2 & $<--$ & Brand_Image & 1.073 & 0.681 & 8.653 & $* * *$ \\
\hline AS3 & $<--$ & Brand_Image & 0.995 & 0.612 & 7.567 & $* * *$ \\
\hline AS4 & $<--$ & Brand_Image & 1.177 & 0.750 & 7.963 & $* * *$ \\
\hline AS5 & $<--$ & Brand_Image & 1.177 & 0.720 & 7.785 & $* * *$ \\
\hline AF2 & $<--$ & Brand_Experience & 0.768 & 0535 & 3.141 & 0.002 \\
\hline SE1 & $<--$ & Brand_Experience & 1.000 & 0.724 & & \\
\hline RE2 & $<--$ & Customer_Loyalty & 0.698 & 0.713 & 3.386 & $* * *$ \\
\hline RE1 & $<--$ & Customer_Loyalty & 1.000 & 0.968 & & \\
\hline
\end{tabular}

Sumber : Olahan Peneliti 2011

\section{Analisis Uji Kelayakan SEM}

Model persamaan struktural penelitian diukur dengan menggunakan teknik analisis persamaan struktural atau structural equation model (SEM). Untuk menguji teknik SEM secara mudah, peneliti menggunakan software AMOS versi 18.

Tabel 7 menunjukan hasil analisis SEM yang melibatkan 240 responden yang dirangkum dalam tabel indeks pengujian kelayakan SEM.

Tabel 7. Indeks Pengujian Kelayakan SEM

\begin{tabular}{|c|c|c|c|}
\hline GOF & $\begin{array}{c}\text { Nilai } \\
\text { Kritis }\end{array}$ & $\begin{array}{c}\text { Hasil } \\
\text { Model }\end{array}$ & $\begin{array}{c}\text { Evaluasi } \\
\text { Model }\end{array}$ \\
\hline RMR & $\leq 0,05$ & 0,032 & $\begin{array}{c}\text { Acceptable } \\
\text { Fit }\end{array}$ \\
\hline $\begin{array}{c}\text { CMIN/ } \\
\text { DF }\end{array}$ & $\leq 2,00$ & 1,705 & $\begin{array}{c}\text { Acceptable } \\
\text { Fit }\end{array}$ \\
\hline RMSEA & $\leq 0,08$ & 0,054 & Close Fit \\
\hline GFI & $\begin{array}{c}0,01- \\
1,00\end{array}$ & 0,938 & Good Fit \\
\hline AGFI & $\begin{array}{c}\geq 0,08- \\
\geq 0,90\end{array}$ & 0,904 & Perfect Fit \\
\hline CFI & $\geq 0,90$ & 0,959 & Good Fit \\
\hline \multicolumn{3}{|c|}{ Sumber : Olahan Peneliti 2011 } \\
\hline
\end{tabular}

Berdasarkan Tabel 7 dapat disimpulkan bahwa semua kriteria indeks pengujian kelayakan SEM telah terpenuhi karena semua kriteria mempunyai nilai di atas batas cut off. 


\section{Analisis Hasil Pengujian Hipotesis Penelitian}

Hasil pengujian hipotesis dalam penelitian dapat dilihat pada tabel 5.10. yang menggambarkan kelima hipotesis yang ada yang dengan hasil analisis penelitian menunjukan hasil yang signifikan. Hasil yang signifikan didapat karena nilai critical ratio (CR) yang dihasilkan lebih besar \pm 1,96. Hasil ini sesuai dengan pernyataan Hair et al. $(1998,623)$ bahwa hubungan yang signifikan dapat ditentukan berdasarkan nilai kritis atau critical ratio di atas \pm 1,96 .

Pengujian hipotesis juga melihat nilai signifikansi $p$-value dengan tingkat signifikan sebesar 0,1 (tingkat error sebesar 10\%). Dengan demikian, hipotesis yang mempunyai tingkat signifikan yang lebih kecil dari 0,1, diterima pada penelitian ini.

Tabel 8. Model Hubungan Struktural, Standardized Regression Weight, dan Critical Ratio

\begin{tabular}{|c|l|c|c|c|l|}
\hline $\begin{array}{c}\text { Hipo- } \\
\text { tesis }\end{array}$ & \multicolumn{1}{|c|}{ Path } & $\begin{array}{c}\text { Standard Regression } \\
\text { Weights }\end{array}$ & CR & P & \multicolumn{1}{|c|}{$\begin{array}{c}\text { Evaluasi Hasil } \\
\text { Hipotesis }\end{array}$} \\
\hline $\mathbf{H}_{1}$ & $\begin{array}{l}\text { Brand Image } \leftarrow \text { Customer } \\
\text { Satisfaction }\end{array}$ & $-0,060$ & - & 0.480 & Ditolak \\
\hline $\mathbf{H}_{2}$ & $\begin{array}{l}\text { Brand Image } \leftarrow \\
\text { Brand Experience }\end{array}$ & 0.075 & 0.706 & 0.468 & Ditolak \\
\hline $\mathbf{H}_{3}$ & $\begin{array}{l}\text { Customer Loyalty } \leftarrow \text { Customer } \\
\text { Satisfaction }\end{array}$ & $-0,164$ & - & 0.041 & Diterima \\
\hline $\mathbf{H}_{4}$ & $\begin{array}{l}\text { Customer Loyalty } \leftarrow \text { Brand } \\
\text { Experience }\end{array}$ & 0.214 & 1.898 & 0.058 & Diterima \\
\hline $\mathbf{H}_{5}$ & $\begin{array}{l}\text { Customer Loyalty } \leftarrow \text { Brand } \\
\text { Image }\end{array}$ & 0.152 & 2.023 & 0.043 & Diterima \\
\hline
\end{tabular}

Sumber : Olahan Peneliti 2011

Dari hasil nilai signifikansi p-value pada Tabel 8 dapat dikatakan bahwa di antara kelima hipotesis yang diuji pada penelitian ini, yaitu H1- H5, hipotesis yang didukung oleh penelitian ini adalah H3, H4, dan H5. Sedangkan, H1 dan H2 ditolak karena memiliki nilai dengan tingkat signifikan di atas 0,1 .

Dengan demikian, persamaan struktural yang didapat dari hasil penelitian yaitu:

$\eta$ Customer Loyalty $=-1,920 \gamma$ customer satisfaction $+0,320 \gamma$ brand experience $+0,257 \beta$

$$
\text { brand image }+0,653 \zeta
$$


Persamaan di atas dapat dijabarkan sebagai persamaan customer loyalty yang memiliki nilai loading sebesar -1,920 untuk konstruk customer satisfaction, 0,320 untuk kosntruk brand experience, 0,257 untuk konstruk brand image, dan 0,653 untuk nilai error. Nilai $\zeta$ sebesar 0,653 diartikan terdapat faktor lain sebesar $65,3 \%$ yang mempengaruhi customer loyalty yang tidak diikutsertakan pada penelitian ini.

Dari persamaan struktural yang dihasilkan, dapat disimpulkan bahwa yang mempunyai pengaruh paling besar atas customer loyalty dari ketiga konstruk yang mempengaruhinya adalah brand experience, kemudian brand image, dan yang mempunyai pengaruh tidak linear adalah customer satisfaction. Pengaruh tidak linear disini terjadi ketika customer loyalty meningkat, maka customer satisfaction akan menurun, dan begitu juga sebaliknya. Pembahasan lengkap mengenai pengaruh tidak linear akan dibahas lebih lanjut pada bagian pembahasan hipotesis.

$\eta$ Brand image $=-0,042 \gamma$ customer satisfaction $+0,066 \gamma$ brand experience $+0,246 \zeta$

Persamaan di atas dapat dijabarkan sebagai persamaan brand image yang memiliki nilai loading sebesar -0,042 untuk konstruk customer satisfaction, 0,066 untuk kosntruk brand experience, dan 0,246 untuk nilai error. Nilai $\zeta$ sebesar 0,246 diartikan terdapat faktor lain sebesar 24,6\% yang mempengaruhi brand image yang tidak diikutsertakan pada penelitian ini.

Dari persamaan struktural yang dihasilkan, dapat disimpulkan bahwa yang mempunyai pengaruh paling besar atas brand image dari kedua konstruk eksogen yang mempengaruhinya adalah brand experience, sedangkan customer satisfaction mempunyai pengaruh yang tidak linear terhadap brand image.

\section{Kesimpulan dan Saran}

\section{Kesimpulan}

Berdasarkan hasil penelitian yang telah dijelaskan, maka dapat diambil kesimpulan sebagai berikut:

1) $\mathrm{H} 1$ dan $\mathrm{H} 2$ tidak didukung dari hasil penelitian, sehingga dapat disimpulkan bahwa tidak terdapat hubungan antara customer satisfaction dengan brand image GMP dan brand experience dengan brand image GMP. 
2) $\mathrm{H} 3, \mathrm{H} 4$, dan $\mathrm{H} 5$ didukung dari hasil penelitian, sehingga dapat disimpulkan bahwa terdapat hubungan antara customer satisfaction dengan customer loyalty GMP, brand experience dengan customer loyalty GMP, dan brand image dengan customer loyalty GMP.

3) H4 dan H5 merupakan hipotesis yang didukung yang mempunyai hubungan yang linear (sebanding) antara variabel antiseden dan konsekuennya, sedangkan H3 merupakan hipotesis yang didukung pada penelitian ini, namun mempunyai hubungan yang nonlinear (berbanding terbalik) antara variabel antiseden dan konsekuennya.

4) Brand Image sebagai variabel intervening pada model penelitian dengan variabel antiseden customer satisfaction dan brand experience tidak mempunyai pengaruh, seperti yang ditunjukan dari hasil penelitian.

5) Asumsi dalam teknik analisis Structural Equation Model (SEM), yang meliputi pengukuran convergent validity, AVE, construct reliability, discriminant validity, uji normalitas, dan uji outlier, telah terpenuhi dari hasil pengujian asumsi SEM.

6) Indeks pengujian kelayakan dalam SEM, meliputi RMR, CMIN/DF, RMSEA, GFI, AGFI, dan CFI, untuk model penelitian ini telah memenuhi kriteria batas cut off untuk masingmasing fit index dan menghasilkan model struktural SEM yang baik.

\section{Saran}

Berdasarkan hasil penelitian dan kesimpulan yang diperoleh pada penelitian, maka peneliti ingin memberikan saran bagi pihak Mal X dan saran bagi penelitian selanjutnya, yaitu sebagai berikut:

1) Hasil penelitian menunjukan bahwa $\mathrm{H} 1$ dan $\mathrm{H} 2$ pada model penelitian tidak didukung karena mempunyai nilai $p$-value yang kurang signifikan. Hal ini mencerminkan bahwa kaitan antara customer satisfaction dan brand experience pengunjung Mal X tidak mempunyai hubungan yang signifikan terhadap brand image GMP. Dapat disimpulkan bahwa brand image sebagai variabel intervening tidak mempunyai pengaruh terhadap customer satisfaction dan brand experience konsumen Mal X. Pada penelitian selanjutnya, brand image sebagai variabel intervening dapat dihilangkan atau diubah menjadi salah satu variabel independent untuk mendapatkan model penelitian yang lebih sesuai.

2) Persamaan $\mathrm{H} 3$ yang menghasilkan hasil yang negatif atau berbanding terbalik antara customer satisfaction dan brand image menyatakan bahwa apabila konsumen merasa puas terhadap Mal X maka belum tentu mereka akan menjadi loyal dengan Mal X. Selain karena 
disebabkan oleh faktor bahwa sepanjang daerah Gajah Mada Plaza dan berseberangan dengan Jalan Hayam Wuruk yang mempunyai mal yang cukup banyak di daerah tersebut dan mengakibatkan ketatnya persaingan antar mal yang juga menarik perhatian konsumen dan tidak menimbulkan perilaku loyal, faktor lain juga dapat disebabkan dari pemilihan responden maupun hal lainnya yang didapat konsumen dari mal lainnya yang tidak didapatkan di Mal X. H3 menunjukan bahwa customer satisfaction adalah salah satu faktor yang didukung pada penelitian ini dan mempunyai pengaruh terhadap customer loyalty, walaupun mempunyai hubungan nonlinear (berbanding terbalik) atau negatif. Mal X diharapkan dapat meningkatkan kepuasan konsumen di GMP seperti dengan melakukan program promosi, penambahan tenants di Mal X, pengadaan events yang menarik bagi konsumen, dan kegiatan lainnya yang dapat menambah kepuasan konsumen. Dengan demikian, diharapkan pada penelitian selanjutnya hubungan customer satisfaction dengan customer loyalty akan mempunyai pengaruh yang positif atau linear.

3) H4 menunjukan bahwa brand experience merupakan salah satu faktor yang didukung pada penelitian ini dan mempunyai pengaruh yang positif terhadap customer loyalty. Berdasarkan hasil penelitian juga, brand experience mempunyai pengaruh yang paling kuat terhadap customer loyalty. Peneliti berharap Mal X dapat meningkatkan kualitas pengalaman belanja konsumen di mal Mal X dengan memberikan pengalaman belanja yang berkesan kepada konsumen dan memenuhi harapan konsumen. Pengalaman konsumen selama di Mal X dapat menjadi penilaian konsumen terhadap loyalitas konsumen untuk ke depannya. Oleh karena itu, Mal X diharapkan dapat memberikan pengalaman belanja yang unik dan berkesan bagi konsumen sehingga konsumen merasa suka untuk datang secara rutin dan berkala di Mal X. Hal ini dapat diwujudkan seperti dengan memberikan promosi dalam harga dan rewards maupun promosi bagi konsumen yang loyal.

4) H5 menunjukan bahwa brand image merupakan salah satu faktor yang didukung pada penelitian ini dan mempunyai pengaruh langsung positif terhadap customer loyalty. Mal X diharapkan dapat meningkatkan brand image mereka di mata konsumen untuk ke depannya sehingga dapat memberikan persepsi dan pandangan bagus konsumen mengenai Mal X dan menciptakan sikap loyal konsumen terhadap Mal X.

5) Model penelitian pada penelitian ini dapat diuji lagi dengan menggunakan sampling atau objek penelitian yang berbeda, sehingga dapat memperoleh hasil yang lebih signifikan. Pada penelitian selanjutnya, penelitian dapat menggunakan metode probabilitas sehingga hasilnya dapat digeneralisasi dan menghasilkan hasil penelitian yang lebih akurat jika dibandingkan dengan metode sampling nonprobabilitas. 
6) Pembuatan konsep indikator-indikator (atau variabel manifes) yang bersifat reflektif terhadap konstruk (atau variabel laten) dapat lebih diperjelas dengan melihat karakteristik dan konteks dari objek penelitian. Dengan indikator yang jelas, mudah dipahami, dan sesuai dengan tujuan pengumpulan data, responden dapat lebih mudah terfokus sehingga pengumpulan data primer dapat lebih akurat dan konsisten dengan tolak ukur penelitian.

7) Dengan memperhatikan karakteristik dari penelitian yang mempunyai unsur kebaruan dalam penelitian itu sendiri, maka disarankan untuk penelitian selanjutnya topik yang akan diteliti yang berkaitan dengan brand image dan customer loyalty suatu mal, dapat dikaitkan dengan unsur positioning dan segmenting mal tersebut dan perkembangannya seiring dengan munculnya banyak mal kompetitor lainnya yang juga dapat menarik ataupun merebut perhatian konsumen secara lebih intensif. Unsur kebaruan penelitian ini menjadi penting karena memberikan manfaat dalam mendeteksi masalah yang dihadapi oleh mal dalam menjaga konsumen mereka dan upaya meningkatkan kualitas untuk ke depannya.

\section{Daftar Pustaka}

Aaker, David A. Managing Brand Equity: Capitalizing on the Value of a Brand Name. New York, NY: Free Press, 1991.

Aaker, David A. dan George S. Day. Marketing Research, $4^{\text {th }}$ ed. Singapore: John Wiley \& Sons, Inc., 1990.

Alloza A. "Brand Engagement and Brand Experience at BBVA, The Transformation of a 150 years old Company”. Corporate Reputation Review Vol.11, (April 2008): 371-81.

Baek, T.H., J. Kim, dan J.H. Yu. "The Differential Roles of Brand Credibility And Brand Prestige in Consumer Brand Choice”. Psychology \& Marketing, no. 27(7), (2010): 662-78.

Baran, R.T., R.J. Galka, dan D.P. Strunk. Principles of Customer Relationship Management. OH: Thomson South Western, 2008.

Brakus, J.J, B.H. Schmitt, dan L. Zarantonello. (2009). "Brand experience: What is it? How is it measured? Does it Affect Loyalty?” Journal of Marketing Vol. 73 (2009): 52-68.

Clifton, Rita dan John Simmons. Brands and Branding. London: Profile Books, Ltd., 2003.

Davis, S.M. Brand Asset Management: driving profitable growth through your brand. California : Jossey-Bass, Inc., 2000. 
Dimitriades, Z.S. "Customer Satisfaction, Loyalty, and Commitment in Service Organization: Some Evidence from Greece.” Management Research News 29 (Desember 2006): 792800 .

Duncan, Tom. Principles of Advertising \& IMC, $2^{\text {nd }}$ ed. New York, NY: McGraw-Hill Education, 2008.

Effendy, Onong Uchjana. Ilmu Komunikasi Teori \& Praktek. Bandung: PT Remaja Rosdakarya, 1998.

Effendy, Onong Uchjana. Metode Penelitian Komunikasi. Bandung: PT Remaja Rosdakarya, 2002.

Faircloth, J.B., L.M. Capella, dan B.L. Alford. "The Effect of Brand Attitude and Brand Image on Brand Equity”. Journal of Marketing Theory and Practic Vol.9, no. 3 (2001): 61-74.

Ferdinand, Agusty. Structural Equation Modeling dalam Penelitian Manajemen: Aplikasi Model-model Rumit dalam Penelitian untuk Tesis Magister dan Desertasi Doktor, $2^{\text {nd }}$ ed. Semarang: Fakultas Ekonomi UNDIP, 2002.

Ganesh, J., M.J. Arnold, M. J. dan K.E. Reynolds. "Understanding the Customer Base of Service Providers: An Examination of the Differences between Stayers and Switchers". Journal of Marketing, no. 64(3), (2000):65-87.

Ghozali, Imam. Aplikasi Analisis Multivariat dengan Program SPSS, $3^{\text {rd }}$ ed. Semarang: Universitas Diponegoro, 2005.

Gibson, Donnelly dan Konopaske Ivancevich. Organizational Behavior. 2006.

Griffin, Jill. Customer Loyalty, How to Earn it, How to Keep it. New York: Lexington Books, 1995.

Hair, Joseph F., W.C. Black, B.J. Babin, R.E. Anderson, dan R.L. Tatham. Multivariate Data Analysis, $5^{\text {th }}$ ed. Englewood Cliffs, NJ: Prentice Hall, 1998.

Hair, Joseph F., W.C. Black, B.J. Babin, R.E. Anderson, dan R.L. Tatham. Multivariate Data Analysis, $6^{\text {th }}$ ed. Upper Sadle River, NJ: Prentice Hall, 2006.

Hair, Joseph F., Arthur H. Money, Philip Samouel, dan Mike Page. Research Methods for Business. England: John Wiley \& Sons, Inc., 2007.

Hair, Joseph F., Robert P. Bush, dan David J. Ortinau. Marketing Research, International Ed. Singapore: McGraw-Hill, 2000. 
Harian Seputar Indonesia. "Panggung Besar di Pusat Belanja". Seputar Indonesia Online. Diambil dari http://www.seputar-indonesia.com/edisicetak/content/view/362529/; Internet; Diakses 18 Oktober 2011.

Harian Seputar Indonesia. "Peizinan Mal Terlalu Longgar”. Seputar Indonesia Online. Diambil dari http://www.seputar-indonesia.com/edisicetak/content/view/340278/; Internet; Diakses 2 Oktober 2011.

Hsieh, M.H., S.L. Pan, dan R. Setiono. "Product-, corporate-, and country-image dimensions and purchase behavior: a multicountry analysis", Journal of the Academy of Marketing Science Vol. 32 No. 3, (2004): 251-70.

Kasper, Hanz, Pie van Heldingen, dan Wouter de Vries Jr. Service Marketing Management: An International Perspective. Chichester, NJ: Prentice Hall, 2006.

Keller, Kevin Lane. "Conceptualizing, Measuring, and Managing Customer-based Brand Equity". Journal of Marketing, no.57(1), (1993): 4-7.

Keller, Kevin Lane. Strategic Brand Communication: Building, Measuring, and Managing Brand Equity, $3^{\text {rd }}$ ed. Upper Saddle River, NJ: Pearson Education, Inc., 2008.

Kotler, Philip. Marketing Management, $11^{\text {th }}$ ed. Upper Saddle River, NJ: Pearson Education, Inc., 2003.

Kotler, P. dan Kevin Lane Keller. Marketing Management, $12^{\text {th }}$ ed. Upper Saddle River, NJ: Prentice Hall, 2006.

Kountur, Ronny. Metode Penelitian untuk Penulisan Skripsi dan Tesis, edisi revisi. Jakarta: PPM, 2007.

Landa, Robin. Designing Brand Experience. New York, NY: Thomson Delmar Learning, 2006.

Littlejohn, Stephen W. dan Karen A. Foss. Theories of Human Communication, $9^{\text {th }}$ ed. USA: Thomson Wadsworth, 2008.

Malhotra, Naresh K. Basic Marketing Research: Application to Contemporary Issues. Upper Saddle River, NJ: Prentice Hall, 2002.

Media Indonesia. “Mal di Daerah Mulai Lirik Konsep Entertainment dan Dining”. Media $\begin{array}{llll}\text { Indonesia } & \text { Online. } & \text { Diambil }\end{array}$ http://www.mediaindonesia.com/read/2011/04/20/219470/21/2/Mal-di-Daerah-MulaiLirik-Konsep-Entertainment-dan-Dining; Internet; Diakses 10 September 2011. 
Mowen, J.C. dan Michael S. Minor. Consumer Behavior: A Framework. Upper Saddle River, NJ: Prentice Hall, 2001.

Nazir, Moh. Metode Penelitian. Bogor: Ghalia Indonesia, 2005.

Rangkuti, Freddy. The Power of the Brand: Teknik Mengelola Brand Equity dan Strategi Pengembangan Merek + Analisis Kasus dengan SPSS. Jakarta: PT Gramedia Pustaka Utama, 2002.

Ouwersloot, Hans dan Tom Duncan. Intergrated Marketing Communication, European Edition. New York, NY: McGraw-Hill Education, 2008.

Park, C. W., B.J. Jaworski, dan D.J. Maclnnis. "Strategic brand concept-image Management". Journal of Marketing, no. 50(4), (1986): 135-45.

Peter, J. P. dan J.C. Olsen. Consumer Behavior and Marketing Strategy, $8^{\text {th }}$ ed. New york: McGraw Hill, Inc., 2008.

Santoso, Singgih. Structural Equation Modelling: Konsep dan Aplikasi dengan AMOS. Jakarta: PT Elex Media Komputindo, 2011.

Sarjono, Haryadi dan Winda Julianita. SPSS vs LISREL: Sebuah Pengantar Aplikasi untuk Riset. Jakarta: Salemba Empat, 2011.

Sekaran, Uma. Research Methods for Business, $4^{\text {th }}$ ed. California, CA: John Wiley and Sons, 2003.

Sheth, Jagdish dan Mital Banwari. Consumer Behavior: A Managerial Perspective, $2^{\text {nd }}$ ed. OH: Thomson SouthWestern, 2004.

Singarimbun, Masri dan Effendi. Metode Penelitian Survai. Jakarta: LP3S, 1989.

Solomon, Michael R. Consumer Behavior: Buying, Having, and Being, $8^{\text {th }}$ ed. Upper Saddle River, NJ: Prentice Hall, 2009.

Tanidi, Aditya. "Pengaruh Customer Experience dan Service Quality dalam Pembentukan Loyalitas Konsumen.” Jurnal Pemasaran, vol.1 (2006): 38-50.

Tempo. "Setelah Jakarta dikepung Mal". Tempo Interaktif Online. Diambil dari http://majalah.tempointeraktif.com/id/arsip/2006/10/30/OPI/mbm.20061030.OPI122116.id .html; Internet; Diakses 5 September 2011.

Tempo Volume 33 Issues 37-43. Jakarta: Press Jajasan Jaya Raya, [2004].

Umar, Husein. Metode Riset: Perilaku Konsumen Jasa. Jakarta: Ghalia Indonesia, 2003. 
Usman, Husain. Pengantar Statistika. Jakarta: Bumi Aksara, 2003.

Vivanews. "Jumlah Mal di Jakarta Sudah tak Ideal". Vivanews online. Diambil dari http://metro.vivanews.com/news/read/165684-jumlah-mal-di-jakarta-sudah-tak-ideal; Internet; Diakses 5 September 2011.

West, Richard dan Turner, Lynn H. Introducing Communication Theory: Analysis and Application, $3^{\text {rd }}$ ed. New York: McGraw-Hill, 2007.

Zarantenello, L dan Schmitt, BH. "Using The Brand Experience Scale to Profile Consumers And Predict Consumer Behavior”. Brand Management Vol.17, no. 7, (2000): 532-40.

Zikmund, William. "Experimental Approach to Investigating Satisfaction and Continuity in Marketing Alliances.” Journal of Marketing Jagdish (2003). 